J. AMer. Soc. Hort. Sci. 116(5):906-910. 1991.

\title{
Fruit Set, Pollen Fertility, and Combining Ability of Selected Tomato Genotypes under High- temperature Field Conditions
}

\author{
Fenny Dane, A. Gene Hunter, and Oyette L. Chambliss
}

Department of Horticulture and Alabama Agricultural Experiment Station, Auburn University, Auburn, AL 36849-5408

\begin{abstract}
Additional index words. Lycopersicon esculentum, heat stress, heat tolerance, stigma exsertion, stigma browning, diallel analysis, combining abilities

Abstract. Selected tomato (Lycopersicon esculentum Mill) genotypes were evaluated for their fruit-setting ability under high-temperature field conditions. A temperature-controlled greenhouse study was conducted to determine the percent fruit set from the total number of flowers and fruit produced per plant. Ratings for set obtained under hightemperature field conditions were significantly $(P=0.001)$ correlated with percent fruit set determined under similar greenhouse conditions. Most of the Asian Vegetable Research and Development Center (AVRDC) selections, Beaverlodge lines, 'Nagcarlan', and 'Red Cherry' could be considered heat-tolerant. Small-fruited, abundantly flowering genotypes were less affected by heat stress than larger-fruited cultivars. Prolonged periods of high temperature caused drastic reductions in pollen fertility in most genotypes, except 'Red Cherry' and $L$. esculentum var. cerasiforme (PI 190256). Stigma browning and stigma exsertion commonly occurred on all lines, except AVRDC CL-5915-553 and PI 190256. Diallel analyses indicated that pollen fertility and fruit set under high field temperatures were primarily under additive gene control.
\end{abstract}

High day and night temperature are known to cause drastic reductions in tomato flowering and fruit set (Abdalla and Verkerk, 1968; Kuo et al., 1979; Rudich et al., 1977) and in fruit size and quality (El Ahmadi and Stevens, 1979a; Hanna and Hernandez, 1982; Iwahori and Takahashi, 1964; Levy et al., 1978). Flowering phases most sensitive to high temperature (40C for 3 to $4 \mathrm{~h}$ ) were during meiosis ( 8 to 9 days before anthesis) and fertilization (1 to 3 days after anthesis) (Iwahori, 1965, 1966; Iwahori and Takahashi, 1964; Sugiyama et al., 1966). Failure of fertilization after exposure to heat mainly could be attributed to decreases in pollen germination and pollen tube elongation (Iwahori, 1966; Weaver and Timm, 1989).

Wide genotypic variation among cultivars has been observed in the effect of high temperature on pollen and ovule production and viability, pollen dehiscence; pollination effectiveness (Shelby et al., 1978), style elongation (El Ahmadi and Stevens, 1979a; Rudich et al., 1977), splitting of the antheridial cone, and stigma exsertion (Levy et al., 1978).

El Ahmadi and Stevens (1979b) reported the inheritance of fruit set under high temperature of heat-tolerant genotypes under greenhouse conditions to be additive with moderate heritability. Heritability was low for seed set, but high for stigma exsertion. Hanna et al. (1982) also found additive gene action to be more important than nonadditive gene action for percent fruit set, percent flower drop, and percent undeveloped ovaries under high field temperatures. Our objectives were to evaluate putative heat-tolerant tomato genotypes for their response to high-temperature field conditions in the southeastern United States, to select the best heat-set lines as genetic sources for incorporation in a breeding program, and to determine the inheritance of reproductive characteristics crucial to heat tolerance through diallel analyses.

Received for publication 14 Mar. 1991. Journal no. 11-892299P of the Alabama Agricultural Experiment Station. Appreciation is extended to J.A. McGuire for help with statistical analysis. The cost of publishing this paper was defrayed in part by the payment of page charges. Under postal regulations, this paper therefore must be hereby marked advertisement solely to indicate this fact.

\section{Materials and Methods}

Screening for heat tolerance. Tomato breeding lines from the AVRDC, Taiwan; Canada (Beaverlodge); and Auburn Univ. (AU); plant introductions (PI) from the North Central Plant Introduction Station, Ames, Iowa; and cultivars from commercial companies were evaluated in 1985 and 1986 for their ability to set under high field temperatures at the Wiregrass Substation of the Alabama Agricultural Experiment Station, Headland. A randomized complete-block design with one (observational trial, 1985), two (1985), or three (1986) replications and 10 plants per replication or plot was used. Six-week-old plants were transplanted

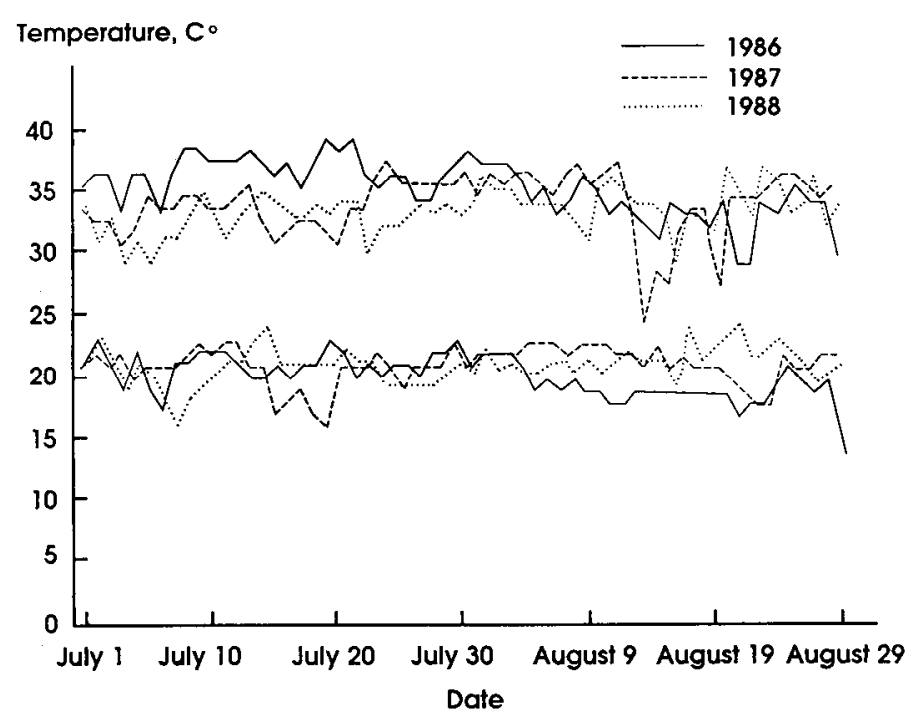

Fig. 1. Daily maxima and minima observed in July and Aug. 1986, 1987 , and 1988 at the Wiregrass Substation in southeastern Alabama.

Abbreviations: AVRDC, Asian Vegetable Research and Development Cente; $\% \mathrm{FS}$, percent fruit set; GCA, general combining ability HS, heat set rating; $\% \mathrm{PF}$, percent pollen fertility. 
Table 1. Average \%FS in the greenhouse, HS, \%PF, stigma browning (SB), and stigma exsertion (SE) of tomato genotypes under high temperatures in the field, 1985 and 1986.

\begin{tabular}{|c|c|c|c|c|c|c|}
\hline \multirow[b]{2}{*}{ Entry } & \multicolumn{6}{|c|}{ Characteristic $^{\mathbf{z}}$} \\
\hline & $\% \mathrm{FS}_{85}$ & $\mathrm{HS}_{85}$ & $\mathrm{HS}_{86}$ & $\% \mathrm{PF}_{86}$ & SB & SE \\
\hline AVRDC PT-3027 & $42.7 \dot{a}$ & $4.3 \mathrm{a}-\mathrm{c}$ & $4.1 \mathrm{ab}$ & $7.7 b-d$ & + & + \\
\hline AVRDC CL-5915-153 & $35.0 \mathrm{ab}$ & $4.3 \mathrm{a}$ & $4.5 \mathrm{ab}$ & $19.3 \mathrm{~b}-\mathrm{d}$ & + & + \\
\hline AVRDC CLN95-392 & $28.8 \mathrm{bc}$ & $2.8 \mathrm{e}-\mathrm{h}$ & $1.5 \mathrm{~g}-1$ & $0.1 \mathrm{~d}$ & + & - \\
\hline AVRDC PT-913 & $28.4 \mathrm{bc}$ & $4.5 \mathrm{ab}$ & $4.0 \mathrm{a}-\mathrm{c}$ & $7.3 \mathrm{~b}-\mathrm{d}$ & + & + \\
\hline Red Cherry & $26.7 b-d$ & $(4.0)^{\mathrm{y}}$ & $4.2 \mathrm{a}$ & $80.6 \mathrm{a}$ & + & - \\
\hline AVRDC CL-5915-553 & $26.6 \mathrm{~b}-\mathrm{d}$ & $3.0 \mathrm{~d}-\mathrm{g}$ & $3.4 \mathrm{a}-\mathrm{e}$ & $2.0 \mathrm{~d}$ & - & - \\
\hline AVRDC PT-4001 & $26.3 b-d$ & $3.5 \mathrm{~b}-\mathrm{e}$ & $2.7 \mathrm{c}-\mathrm{g}$ & $13.0 \mathrm{~b}-\mathrm{d}$ & + & - \\
\hline AVRDC CL-5915-206 & $25.5 \mathrm{~b}-\mathrm{f}$ & $2.9 \mathrm{~d}-\mathrm{h}$ & $2.7 \mathrm{~b}-\mathrm{g}$ & $30.6 \mathrm{~b}-\mathrm{d}$ & + & + \\
\hline AVRDC CLN91-338 & $22.2 \mathrm{c}-\mathrm{g}$ & $2.8 \mathrm{e}-\mathrm{h}$ & $1.5 \mathrm{~g}-1$ & $0.9 \mathrm{~d}$ & + & + \\
\hline Saladette & $21.6 \mathrm{c}-\mathrm{h}$ & $2.8 \mathrm{c}-\mathrm{h}$ & $3.0 \mathrm{a}-\mathrm{f}$ & $12.2 \mathrm{~b}-\mathrm{d}$ & + & - \\
\hline AVRDC CLN95-280 & $20.5 \mathrm{c}-\mathrm{i}$ & $3.3 \mathrm{c}-\mathrm{f}$ & $3.1 \mathrm{a}-\mathrm{e}$ & $2.0 \mathrm{~d}$ & + & - \\
\hline Nagcarlan & $19.0 \mathrm{c}-\mathrm{j}$ & $4.8 \mathrm{a}$ & $2.6 \mathrm{~d}-\mathrm{g}$ & $37.3 \mathrm{~b}$ & + & + \\
\hline AVRDC CLN65-349 & $18.3 \mathrm{~d}-\mathrm{k}$ & $3.3 \mathrm{c}-\mathrm{f}$ & $4.1 \mathrm{ab}$ & $14.8 \mathrm{~b}-\mathrm{d}$ & + & - \\
\hline AVRDC CL-5915-223 & $16.5 \mathrm{e}-1$ & $4.3 \mathrm{a}-\mathrm{c}$ & $3.2 \mathrm{a}-\mathrm{e}$ & $6.2 \mathrm{~cd}$ & + & - \\
\hline PI 272735 & $15.7 \mathrm{f}-1$ & $3.2 \mathrm{c}-\mathrm{f}$ & $2.6 \mathrm{~d}-\mathrm{g}$ & $34.5 \mathrm{bc}$ & + & + \\
\hline AVRDC CL-5915-136 & $15.4 \mathrm{~g}-\mathrm{l}$ & $4.0 \mathrm{a}-\mathrm{d}$ & $2.8 \mathrm{~b}-\mathrm{g}$ & $24.6 \mathrm{~b}-\mathrm{d}$ & + & + \\
\hline Beaverlodge 6808 & $14.8 \mathrm{~g}-1$ & $(4.0)$ & $3.0 a-f$ & $8.8 \mathrm{bc}$ & + & + \\
\hline Karlick & $14.3 \mathrm{~g}-\mathrm{m}$ & $(4.0)$ & $3.6 \mathrm{a}-\mathrm{d}$ & $34.4 \mathrm{bc}$ & + & - \\
\hline Hotset & $13.7 \mathrm{~g}-\mathrm{m}$ & $2.3 \mathrm{f}-\mathrm{i}$ & $2.1 \mathrm{e}-\mathrm{j}$ & $2.9 \mathrm{~d}$ & + & - \\
\hline Beaverlodge 6806 & $12.9 \mathrm{~g}-\mathrm{m}$ & $(4.0)$ & $2.1 e-j$ & $3.2 \mathrm{~d}$ & + & - \\
\hline PI 298633 Pioneer & $12.5 \mathrm{~g}-\mathrm{n}$ & $(3.0)$ & $3.4 \mathrm{a}-\mathrm{e}$ & $9.5 \mathrm{~b}-\mathrm{d}$ & - & + \\
\hline AVRDC CLN95-77 & $12.4 \mathrm{~g}-\mathrm{n}$ & $4.5 \mathrm{ab}$ & $4.1 \mathrm{ab}$ & $10.2 \mathrm{~b}-\mathrm{d}$ & - & + \\
\hline Beaverlodge 6804 & $11.7 \mathrm{~h}-\mathrm{n}$ & $(4.0)$ & $4.0 \mathrm{a}-\mathrm{c}$ & $26.2 \mathrm{~b}-\mathrm{d}$ & + & + \\
\hline AVRDC TN-2, & $11.4 \mathrm{~h}-\mathrm{n}$ & $1.8 \mathrm{ih}$ & $1.6 \mathrm{~g}-1$ & $0.5 \mathrm{~d}$ & + & - \\
\hline Small Fry & $11.0 \mathrm{i}-\mathrm{n}$ & $3.3 \mathrm{c}-\mathrm{f}$ & $2.2 \mathrm{e}-\mathrm{j}$ & $9.5 \mathrm{~b}-\mathrm{d}$ & + & + \\
\hline AVRDC CL-5915-93 & $10.3 \mathrm{i}-\mathrm{o}$ & $4.5 \mathrm{ab}$ & $3.3 \mathrm{a}-\mathrm{e}$ & $26.1 \mathrm{~b}-\mathrm{d}$ & + & + \\
\hline Severianin & $10.3 \mathrm{i}-\mathrm{o}$ & $(3.0)$ & $2.8 \mathrm{~b}-\mathrm{g}$ & $11.5 \mathrm{~b}-\mathrm{d}$ & + & - \\
\hline Coldset & $8.9 \mathrm{j}-\mathrm{o}$ & $(2.5)$ & & & & \\
\hline PI 204998 & $8.4 \mathrm{k}-0$ & $4.0 \mathrm{a}-\mathrm{d}$ & $3.4 \mathrm{a}-\mathrm{e}$ & $26.3 \mathrm{~b}-\mathrm{d}$ & + & - \\
\hline Fresh Market 9 & $7.9 \mathrm{k}-\mathrm{o}$ & $3.0 \mathrm{~d}-\mathrm{g}$ & $3.0 \mathrm{a}-\mathrm{f}$ & $4.1 \mathrm{~cd}$ & + & - \\
\hline AVRDC PT-1707 & $7.81-0$ & $2.8 \mathrm{e}-\mathrm{h}$ & $2.6 \mathrm{~d}-\mathrm{g}$ & $25.4 \mathrm{~b}-\mathrm{d}$ & + & + \\
\hline Tex Rock & $7.51-0$ & $2.8 \mathrm{e}-\mathrm{h}$ & $1.8 \mathrm{f}-\mathrm{k}$ & $11.1 \mathrm{~b}-\mathrm{d}$ & + & - \\
\hline Maliutka & $7.01-0$ & $4.2 \mathrm{a}-\mathrm{c}$ & $2.6 \mathrm{~d}-\mathrm{g}$ & $19.2 \mathrm{~b}-\mathrm{d}$ & + & + \\
\hline Monte Carlo & $6.81-\mathrm{o}$ & $(2.0)$ & $1.3 \mathrm{~h}-1$ & $15.7 b-d$ & + & - \\
\hline Duke & $6.61-0$ & $1.8 \mathrm{ih}$ & & & & \\
\hline Beaverlodge 6810 & $6.51-0$ & $(4.0)$ & & & & \\
\hline Anahu & $6.31-0$ & $(1.0)$ & $1.0 \mathrm{j}-1$ & $2.0 \mathrm{~d}$ & + & - \\
\hline Flora-Dade & $6.31-0$ & $1.5 \mathrm{i}$ & $1.1 \mathrm{i}-1$ & $0.2 \mathrm{~d}$ & + & + \\
\hline Floradel & $4.1 \mathrm{~m} \rightarrow 0$ & $1.3 \mathrm{i}$ & $0.6 \mathrm{kl}$ & $1.7 \mathrm{~d}$ & + & + \\
\hline Tropi-Gro & 2.4 no & $(1.0)$ & & & & \\
\hline Summerset & 0.00 & $(1.0)$ & & & & \\
\hline PI 190256 & & & $3.6 \mathrm{a}-\mathrm{d}$ & $88.2 \mathrm{a}$ & - & - \\
\hline PI 341155 & & & $2.5 \mathrm{~d}-\mathrm{h}$ & $1.7 \mathrm{~d}$ & - & + \\
\hline Chico III & & & $2.4 \mathrm{~d}-\mathrm{i}$ & $7.2 \mathrm{~b}-\mathrm{d}$ & + & - \\
\hline Floramerica & & & $0.6 \mathrm{kl}$ & $0.3 \mathrm{~d}$ & + & - \\
\hline AU-84-M-1 & & & 0.41 & $12.2 \mathrm{~b}-\mathrm{d}$ & + & + \\
\hline AU-76 & & & 0.41 & $0.0 \mathrm{~d}$ & + & + \\
\hline
\end{tabular}

${ }^{2}$ Mean separation within columns by Duncan's multiple range test $(\mathrm{P}=0 . \overline{05})$; + , observed; -, not observed.

${ }^{y} \mathrm{HS}$ determined in observational trial.

each year in mid-June. The daily maximum ranged from 29 to $36 \mathrm{C}$ and the daily minimum from 17 to $24 \mathrm{C}$ in July and Aug. 1985. Daily maxima and minima for 1986 are shown in Fig. 1.

The total number of fruit produced per plant per entry was determined from three harvests during the first 2 weeks of Aug. 1985 and at biweekly intervals from three plants per plot in July and Aug. 1986. Mature flowers (six per plot) were tagged at biweekly intervals in 1986 to calculate the number of fruit set per tagged flower as percent fruit set $(\% \mathrm{FS})$; also, flowers were collected and fixed in a 3 ethanol : $145 \%$ acetic acid solution for pollen fertility determinations. Anthers from at least three flowers per entry were squashed in acetocarmine (Tsuchiya, 1971), and when possible, at least 100 pollen grains per flower were used to determine the percent fertile pollen (\%PF). Pollen visibly filled with cytoplasm was considered fertile. The stigma position in relation to the antheridial cone and stigma coloration were recorded.

All lines were visually rated for their ability to set fruit, using a heat-set rating (HS) with $0=$ no fruit to $5=$ many fruits, similar to Villareal et al. (1978). 
Table 2. Average \%PF of tomato flowers collected at biweekly intervals in Summer 1986.

\begin{tabular}{lccl}
\hline \hline & \multicolumn{3}{c}{$\%$ PF } \\
\cline { 2 - 4 } Entry & $22 \mathrm{July}$ & $7 \mathrm{Aug}$. & 21 . Aug. \\
\hline AVRDC CL-5915-153 & $75.6 \mathrm{a}-\mathrm{c}^{\mathbf{2}}$ & $19.3 \mathrm{bc}$ & $95.2 \mathrm{a}$ \\
Red Cherry & $84.1 \mathrm{ab}$ & $80.6 \mathrm{a}$ & $97.5 \mathrm{a}$ \\
AVRDC CLN65-349 & $47.4 \mathrm{~b}-\mathrm{e}$ & $14.8 \mathrm{bc}$ & $84.3 \mathrm{ab}$ \\
AVRDC PT-3027 & $56.5 \mathrm{a}-\mathrm{d}$ & $7.7 \mathrm{bc}$ & $71.0 \mathrm{a}-\mathrm{c}$ \\
AVRDC CLN95-77 & $28.4 \mathrm{~d}-\mathrm{g}$ & $10.2 \mathrm{bc}$ & $54.6 \mathrm{c}$ \\
Beaverlodge 6804 & $85.5 \mathrm{a}$ & $26.2 \mathrm{bc}$ & $92.4 \mathrm{ab}$ \\
AVRDC PT-913 & $31.4 \mathrm{~d}-\mathrm{g}$ & $7.3 \mathrm{bc}$ & $89.7 \mathrm{ab}$ \\
PI 272735 & $83.9 \mathrm{ab}$ & $34.5 \mathrm{~b}$ & $97.6 \mathrm{a}$ \\
Nagcarlan & $49.4 \mathrm{~b}-\mathrm{d}$ & $37.3 \mathrm{~b}$ & $95.5 \mathrm{a}$ \\
Flora-Dade & $10.6 \mathrm{e}-\mathrm{g}$ & $0.2 \mathrm{c}$ & $65.8 \mathrm{bc}$ \\
Floradel & $40.3 \mathrm{c}-\mathrm{f}$ & $1.7 \mathrm{c}$ & $94.5 \mathrm{a}$ \\
AU-84-M-1 & $9.2 \mathrm{fg}$ & $12.2 \mathrm{bc}$ & $79.8 \mathrm{a}-\mathrm{c}$ \\
AU-76 & $0.6 \mathrm{~g}$ & $0.0 \mathrm{c}$ & $89.7 \mathrm{ab}$ \\
Mean & 46.4 & 24.4 & 85.2 \\
\hline
\end{tabular}

${ }^{z}$ Mean separation within columns by Duncan's multiple range test $(P$ $=0.05$ ).

Table 3. Average HS and GCA of selected tomato genotypes in 10parent nonreciprocal diallel in 1987.

\begin{tabular}{llc}
\hline \hline Entry & HS & GCA $_{\text {Hs }}$ \\
\hline Red Cherry & 3.7 & $0.87 * * *$ \\
Beaverlodge 6804 & 3.3 & $-0.69^{* * *}$ \\
AVRDC CLN-95-77 & 3.0 & 0.29 \\
N a g c a r 1 a n & 2.5 & $0.66^{* * *}$ \\
PI 272735 & 2.1 & $0.27 *$ \\
A VRDC PT-913 & 1.9 & 0.09 \\
Hayslip & & $-0.53^{* * *}$ \\
Suncoast & 0.7 & $-0.62^{* * *}$ \\
Floradel & 0.3 & $-0.71^{* * *}$ \\
Flora-Dade & 0.0 & $-1.01 * * *$ \\
\hline
\end{tabular}

*,***Significant at $\mathrm{P}=0.05$ or 0.001 , respectively.

A temperature-controlled greenhouse study was conducted in 1985 on single-plant plots to determine the \%FS based on the total number of fruit and flowers produced per plant. A randomized complete-block design with four replications was used. The daily maxima ranged from 28 to $36 \mathrm{C}$ and the minima from 22 to $28 \mathrm{C}$ in July and August.

Diallel analyses. Nonreciprocal diallel hybrids between parents selected for their heat tolerance (PT-913, CLN95-77, Beaverlodge 6804, 'Nagcarlan', 'Red Cherry', and PI 272735) or heat sensitivity ('Flora-Dade', 'Floradel', 'Suncoast', and
'Hayslip') were rated for HS in the field in 1987. The design was a randomized complete block with four replications and three plants per plot. In a separate study, six parents and their $\mathrm{F}_{1}$ diallel hybrids were more intensively studied. Percent FS on the first six flower clusters on one plant per plot and \%PF on another plant per plot were determined. Flowers were collected at biweekly intervals in fixative, and where possible, 100 pollen from at least three flowers per entry per replication were analyzed as described.

Reciprocal diallel hybrids among heat-tolerant CL-5915-153, Beaverlodge 6804, 'Nagcarlan', 'Red Cherry', and heat-sensitive AU-76 and AU-84-M-1 were evaluated in 1988 for HS. Flowers collected during the heat-stress period were examined as described.

Parent and $\mathrm{F}_{2}$ lines from the diallel studies and commercial cultivars were evaluated in 1989 for HS in a randomized complete-block design with four replications and 16 plants per plot for parent lines or cultivars and 36 plants per plot for $\mathrm{F}_{2}$ lines. Daily maxima and minima for July and Aug. 1987 and 1988 are shown in Fig. 1. Temperatures observed in 1989 followed a similar pattern, with daily maxima ranging from 28 to $37 \mathrm{C}$ and daily minima from 16 to $27 \mathrm{C}$.

Variables were subjected to regression analysis and to mean separation using Duncan's new multiple range test. General (GCA) and specific (SCA) combining abilities were computed according to Model I, Method 2 in 1987 and Model I, Method 1 in 1988 (Griffing, 1956). The relative importance of GCA and SCA in determining progeny performance was assessed as $2 \times$ $\mathrm{MS}_{\mathrm{GCA}}: 2 \times \mathrm{MS}_{\mathrm{GCA}}+\mathrm{MS}_{\mathrm{SCA}}$ (Baker, 1978). Correlations between $\mathrm{HS}, \% \mathrm{FS}$, mature fruit size, and \%PF were determined.

\section{Results and Discussion}

Screening for heat tolerance. Most of the AVRDC entries and Beaverlodge lines, 'Red Cherry', and 'Nagcarlan' performed well under high temperature in the greenhouse and field (Table 1). The number of fruit produced per plant under high temperature in the greenhouse was highly correlated with the number of fruit produced under high temperature in the field $(r$ $\left.=0.81^{* * *}\right)$. The HS ratings obtained in the field were found to be highly correlated with the average number of fruit produced per plant $\left(r=0.87^{* * *}\right)$, confirming screening studies of Villareal et al. (1978). Small-fruited cultivars generally produced more fruit and showed a higher level of heat tolerance than large-fruited cultivars $(r=-0.42 *$ between $\mathrm{HS}$ rating and fruit size; $r=-0.62 * * *$ between $\% \mathrm{FS}_{\mathrm{GH}}$ and fruit size). HS values obtained in 1985 were highly correlated with those

Table 4. Average HS, \%PF, and estimated GCA of tomato genotypes in a six-parent nonreciprocal diallel in 1987 and six-parent reciprocal diallel in 1988.

\begin{tabular}{|c|c|c|c|c|c|c|c|c|}
\hline \multirow[b]{2}{*}{ Entry } & \multicolumn{8}{|c|}{ Characteristic } \\
\hline & $\mathrm{HS}_{87}$ & $\mathrm{GCA}_{\mathrm{HS}}$ & $\% \mathrm{PF}_{87}$ & $\mathrm{GCA}_{\% \mathrm{PF}}$ & $\mathrm{HS}_{88}$ & $\mathrm{GCA}_{\mathrm{HS}}$ & $\% \mathrm{PF}_{88}$ & $\mathrm{GCA}_{\% \mathrm{PF}}$ \\
\hline CL-5915-153 & 3.7 & $0.47^{* *}$ & 45.6 & -3.69 & 3.4 & $0.38^{* *}$ & 47.2 & $-10.55^{* *}$ \\
\hline Red Cherry & 3.7 & $0.36^{* *}$ & 76.0 & $5.25^{*}$ & 2.0 & $0.21^{* *}$ & 73.2 & 2.69 \\
\hline Beaverlodge & 3.3 & 0.17 & 85.3 & $6.91^{* *}$ & 2.9 & $0.22^{* *}$ & 89.6 & $8.67^{* *}$ \\
\hline Nagcarlan & 2.5 & $0.29^{*}$ & 88.7 & $14.26^{* *}$ & 2.3 & $0.28^{* *}$ & 58.5 & $6.88^{* *}$ \\
\hline CLN-65-349 & 1.3 & $-0.36^{* *}$ & 32.3 & $-9.87 * *$ & & & & \\
\hline Flora-Dade & 0.0 & $-0.94^{* *}$ & 1.1 & $-12.85^{* *}$ & & & & \\
\hline AU-84-M-1 & & & & & 1.3 & $-0.38^{* *}$ & 30.5 & - \\
\hline AU-76 & & & & & 1.0 & $-0.71^{* *}$ & 7.1 & $-7.69^{* *}$ \\
\hline Ratio $^{z}$ & & 0.89 & & 0.81 & & 0.96 & & 0.70 \\
\hline
\end{tabular}

${ }^{2}$ Ratio $=2 \times \mathrm{MS}_{\mathrm{GCA}}:\left(2 \times \mathrm{MS}_{\mathrm{GCA}}+\mathrm{MS}_{\mathrm{SCA}}\right)$.

$*, * *$ Significant at $P=0.05$ or 0.01 , respectively. 
Table 5. Average $\mathrm{HS}$ of selected tomato genotypes and $\mathrm{F}_{2}$ populations in 1989.

\begin{tabular}{ll}
\hline \hline Entry & HS \\
\hline Parent line or cultivar & \\
AVRDC CL-5915-153 & $3.0 \mathrm{a}-\mathrm{e}^{\mathbf{z}}$ \\
Nagcarlan & $3.0 \mathrm{~b}-\mathrm{e}$ \\
Beaverlodge 6804 & $2.9 \mathrm{~b}-\mathrm{e}$ \\
Red Cherry & $2.8 \mathrm{c}-\mathrm{e}$ \\
PI 190256 & $2.4 \mathrm{ef}$ \\
Solar set & $1.9 \mathrm{f}$ \\
Suncoast & $1.3 \mathrm{~g}$ \\
Flora-Dade & $0.9 \mathrm{~g}$ \\
F populations & \\
CL-5915-153 x Beaverlodge & $3.8 \mathrm{a}$ \\
Beaverlodge x Nagcarlan & $3.7 \mathrm{ab}$ \\
CL-5915-153 x Nagcarlan & $3.5 \mathrm{a}-\mathrm{c}$ \\
Nagcarlan $\times$ Red Cherry & $3.2 \mathrm{a}-\mathrm{d}$ \\
Beaverlodge $\times$ Red Cherry & $3.1 \mathrm{a}-\mathrm{e}$ \\
CL-5915-153 x Flora-Dade & $2.8 \mathrm{c}-\mathrm{e}$ \\
CL-5915-153 x Red Cherry & $2.7 \mathrm{~d}-\mathrm{f}$ \\
Red Cherry $\times$ Suncoast & $2.6 \mathrm{~d}-\mathrm{f}$ \\
Nagcarlan $\times$ Flora-Dade & $2.4 \mathrm{ef}$ \\
\hline
\end{tabular}

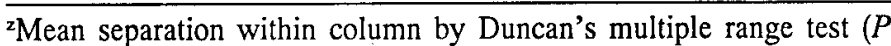
$=0.05$ ).

obtained in $1986\left(r=0.77^{* * *}\right)$. When flowers were tagged at biweekly intervals from mid-July to Aug. 1986, only flowers on a few AVRDC entries (CL-5915-153, CLN95-77, PT-1701), 'Nagcarlan', Beaverlodge (6804 and 6806), and 'Red Cherry' set fruit during heat-stress field conditions.

To better understand the effect of high temperatures on fruit set, pollen fertility of the entries was examined over the growing season in 1986 . Percent pollen fertility was drastically reduced on most entries, except for 'Red Cherry' and $L$. esculentum var. cerasiforme (PI 190256), which showed little to no effect of heat stress on flower morphology (Table 1) or fertility (Table 2). Stigma browning and stigma exsertion were observed frequently in heat-sensitive as well as heat-tolerant genotypes, with the exception of AVRDC CL-5915-553 and PI 190256. Shriveled flowers with split antheridial cones occurred less frequently. Flowers collected after prolonged periods of heat stress generally showed drastic reductions in pollen fertility, while PF values showed increases as day and night temperatures decreased later in the season (Table 2). Smaller-fruited lines generally were less affected by high temperature than others, as indicated by highly significant negative correlations between $\% \mathrm{PF}$ and mature fruit size $\left(r=-0.61^{* * *}\right)$ and $\mathrm{HS}$ rating and mature fruit size $\left(r=-0.40^{* *}\right)$ in the 1986 study. The positive correlations found between $\mathrm{HS}$ and $\% \mathrm{PF}\left(r=0.44^{* *}\right)$ and between TF and \%PF ( $\left.r=0.74^{* * *}\right)$ indicate that heat-tolerant lines generally maintained a higher level of pollen fertility throughout the season than heat-sensitive lines. Reductions in pollen fertility under high temperatures have been reported in the literature (El Ahmadi and Stevens, 1979a; Kuo et al., 1979; Rudich et al., 1977; Weaver and Timm, 1989), but small-fruited genotypes were not included in these studies.

Diallel analyses. In the 1987 and 1988 diallel tests, $\mathrm{F}_{1}$ hybrids generally showed more heat tolerance than the parents, consistent with results obtained by El Ahmadi and Stevens (1979b). The variation in HS could largely be attributed to additive gene effects, with the smaller-fruited genotypes showing positive GCA effects and the large-fruited cultivars negative effects (Table 3 ). The ratio $\left(2 \times \mathrm{MS}_{\mathrm{GCA}}: 2 \times \mathrm{MS}_{\mathrm{GCA}}+\mathrm{MS}_{\mathrm{SCA}}\right)$ for HS rating varied from 0.89 to 0.96 , indicating the importance of additive gene action. The correlation between HS rating and \%FS on the first six flower clusters was highly significant $\left(r=0.75^{* * *}\right)$ in the 1987 six-parent diallel. The average \%PF of the parents (72.9\% on 27 July $1987,54.8 \%$ on 10 Aug. $1987,77.2 \%$ on 22 Aug. 1987, and 55.1\% on 9 Aug. 1988), however, was higher than that of their $\mathrm{F}_{1}$ hybrids $(42.5 \%, 35.8 \%, 47.7 \%$, and $38.4 \%$, respectively). PF decreased during the prolonged period of heat stress and increased as temperatures decreased. Heattolerant entries generally maintained a higher level of pollen fertility $(r=0.39 * *$ between HS and \%PF in 1987). A large portion of the combining ability variance for $\% \mathrm{PF}$ was partitioned into the GCA component (Table 4), and nonsignificant maternal and reciprocal components were obtained in the reciprocal diallel.

From diallel analyses in 2 years, we conclude that heat tolerance is primarily under the control of additive genes, which is in agreement with results obtained by El Ahmadi and Stevens (1979b) and Hanna et al. (1982). Decreases in pollen fertility were a limiting factor during prolonged periods of heat stress. Pollen fertility under heat stress was also found to be governed by an additive gene system. Although several small-fruited genotypes maintained a high level of pollen fertility under heat stress, other genotypes, such as 'Nagcarlan' and Beaverlodge 6804 , were better at transferring their degree of heat tolerance to their offspring. This transfer was especially apparent in the 1989 study evaluating $\mathrm{F}_{2}$ populations for $\mathrm{HS}$ (Table 5). $\mathrm{F}_{2}$ populations originating from hybrids between 'Nagcarlan', Beaverlodge 6804, or AVRDC CL-5915-153 significantly outperformed the parent lines in HS rating. Breeding progress for improved fruit set at high temperatures is feasible but, in combination with desirable fresh-market characteristics, has been difficult to achieve. More research clearly needs to be done to uncover the cause of the wide genotypic variation in heat tolerance and determine the relationship between fruit size and heat tolerance and the underlying physiological processes involved.

\section{Literature Cited}

Abdalla, A.A. and K. Verkerk. 1968. Growth, flowering and fruit-set of the tomato at high temperature. Neth. J. Agr. Sci. 16:71-76.

Baker, R.J. 1978. Issues in diallel analysis. Crop Sci. 18:533-536.

Dane, F., O.L. Chambliss, A.G. Hunter, and L. Wells. 1988. Hot weather tomatoes. Highlights for agricultural research 35:4. Quarterly Rpt. Alabama Agr. Expt. Sta., Auburn.

El Ahmadi, A.B. and M.A. Stevens. 1979a. Reproductive responses of heat-tolerant tomatoes to high temperatures. J. Amer. Soc. Hort. Sci. 104:686-691.

El Ahmadi, A.B. and M.A. Stevens. 1979b. Genetics of high-temperature fruit set in the tomato. J. Amer. Soc. Hort. Sci. 104:691696.

Griffing, B. 1956. Concept of general and specific combining ability in relation to diallel crossing systems. Austral. J. Biol. Sci. 9:463493.

Hanna, Y.H. and T.P. Hernandez. 1982. Response of six tomato genotypes under the summer and spring weather conditions in Louisiana. HortScience 17:758-759.

Hanna, Y. H., T.P. Hernandez, and K.L. Koonce. 1982. Combining ability for fruit set, flower drop, and underdeveloped ovaries in some heat-tolerant tomatoes. HortScience 17:760-761.

Iwahori, S. 1965. High temperature injuries in tomato. IV. Development of normal flower buds and morphological abnormalities of flower buds treated with high temperature. J. Jpn. Soc. Hort. Sci. 34:33-41.

Iwahori, S. 1966. High temperature injuries in tomato. V. Fertilization and development of embryo with special reference to the abnormalities caused by high temperature. J. Jpn. Soc. Hort. Sci. 35:55-62. 
Iwahori, S. and K. Takahashi. 1964. High temperature injuries in tomato. III. Effects of high temperature on flower buds and flowers of different stages of development. J. Jpn. Soc. Hort. Sci. 33:6774.

Kuo, C. G., B.W. Chen, M.H. Chou, C.L. Tsai, and T.S. Tsay. 1979. Tomato fruit-set at high temperatures, p. 94-109. In: R. Cowell (ed.). Proc. First Intl. Symp. Trop. Tomato, Asian Veg. Res. Dev. Ctr., Shanhua, Taiwan.

Levy, A., H.D. Rabinowitch, and N. Kedar. 1978. Morphological and physiological characters affecting flower drop and fruit set of tomatoes at high temperatures. Euphytica 27:211-218.

Rudich, J.,. E. Zamski, and Y. Regev. 1977. Genotypic variation for sensitivity to high temperature in the tomato: Pollination and fruit set. Bot. Gaz. 138:448-452.
Shelby, R.A., W.H. Greenleaf, and C.M. Peterson. 1978. Comparative floral fertility in heat tolerant and heat sensitive tomatoes. J. Amer. Soc. Hort. Sci. 103:778-780.

Sugiyama, T., S. Iwahori, and K. Takahashi. 1966. Effect of high temperature on fruit setting of tomato under cover. Acta Hort. 4:6369.

Tsuchiya, T. 1971. An improved acetocarmine squash method, with special reference to the modified Rattenburg's method of making a preparation permanent. Barley Genet. Nwsl. 1:71-73.

Villareal, R. L., S.H. Lai, and S.H. Wong. 1978. Screening for heat tolerance in the genus Lycopersicon. HortScience 13:479-481.

Weaver, M.L. and H. Timm. 1989. Screening tomato for high-temperature tolerance through pollen viability tests. HortScience 24:493495. 